\title{
SISTEM PERLINDUNGAN ATAS CIPTAAN BERDASARKAN UNDANG-UNDANG NOMOR 28 TAHUN 2014 TENTANG HAK CIPTA DALAM PERSPEKTIF CYBER LAW
}

\author{
Sudjana \\ email:sdjana@yahoo.com
}

\begin{abstract}
The purpose of this article is to discuss, from the perspective of cyber law, the relevant rules and regulation as found in the prevailing law on copyright (Law No. 28 of 2014) and how it provides effective protection to copyright creations. The author shall highlight the most important rules and norms or principles. The discussion shows that a number of rules in the Law No. 28 of 2014 has not been able to fully accommodate the need to respond to new development in virtual technology. A number of issues concerning who enjoy protection, the object being protected, registration system, period of protection, restriction on copyright and its relation to educational interest and scientific research still needs to be regulated in detail.
\end{abstract}

Keywords:

protection systems, creation, Copy Right, Cyber Law.

\begin{abstract}
Abstrak
Fokus tulisan ini adalah atas telaahan pada sistem perlindungan atas ciptaan berdasarkan UndangUndang Nomor 28 Tahun 2014 Tentang Hak Cipta dalam Perspektif Cyber Law. Di dalam penelitian ini ketentuan-ketentuan yang relevan dan kaidah yang tersembunyi di dalamnya akan digambarkan serta, dianalisis untuk memberikan jawaban atas persoalan yang diajukan. Hasil kajian menunjukkan beberapa ketentuan yang mengatur sistem perlindungan atas ciptaan berdasarkan Undang-Undang Nomor 28 tahun 2014 belum sepenuhnya mengakomodasi perkembangan teknologi informasi secara virtual, yakni mengenai subyek perlindungan, obyek perlindungan, stelsel pendaftaran, jangka waktu, pembatasan hak cipta dan kepentingan pendidikan dan penelitian.
\end{abstract}

Kata Kunci:

Sistem Perlindungan, Ciptaan, UU Hak Cipta, Cyber Law.

\section{Pengantar}

Secara historis ${ }^{1}$ di Indonesia, peraturan perundang-undangan di bidang Kekayaan Intelektual, khususnya Hak Cipta telah ada sejak tahun 1840. Pemerintah kolonial Belanda mengesahkan Undang-Undang Cipta tahun 1912. Indonesia yang pada waktu itu masih bernama Netherlands East-Indies telah

\footnotetext{
${ }^{1}$ http://id.wikipedia.org/wiki/Kekayaan_intelektual. (terakhir diakses 10 Agustus 2015).
} 
menjadi angota Paris Convention for the Protection of Industrial Property sejak tahun 1888, anggota Madrid Convention dari tahun 1893 sampai dengan 1936, dan anggota Berne Convention for the Protection of Literary and Artistic Works sejak tahun 1914. Kemudian pada tanggal 15 April 1994 Pemerintah RI menandatangani Final Act Embodying the Result of the Uruguay Round of Multilateral Trade Negotiations, yang mencakup Agreement on Trade Related Aspects of Intellectual Property Rights (Persetujuan TRIPS).

Pada tahun 2014, disahkan Undang-Undang Nomor 28 Tahun 2014 (selanjutnya disebut UUHC) menggantikan Undang-Undang Nomor 19 Tahun 2002 karena Undang-undang tersebut dianggap sudah tidak sesuai dengan perkembangan hukum dan kebutuhan masyarakat. ${ }^{2}$ Langkah Dewan Perwakilan Rakyat Republik Indonesia dan Pemerintah mengganti UUHC 2002 dengan Undang-Undang ini adalah upaya sungguh-sungguh dari negara untuk melindungi hak ekonomi dan hak moral Pencipta dan Pemilik Hak Terkait sebagai unsur penting dalam pembangunan kreativitas nasional. Teringkarinya hak ekonomi dan hak moral dapat mengikis motivasi para Pencipta dan Pemilik Hak Terkait untuk berkreasi. Hilangnya motivasi seperti ini akan berdampak luas pada runtuhnya kreativitas makro bangsa Indonesia. Bercermin kepada negara-negara maju tampak bahwa pelindungan yang memadai terhadap Hak Cipta telah berhasil membawa pertumbuhan ekonomi kreatif secara signifikan dan memberikan kontribusi nyata bagi perekonomian dan kesejahteraan rakyat. ${ }^{3}$

Perkembangan teknologi informasi dan komunikasi telah menjadi salah satu variabel dalam Undang-Undang tentang Hak Cipta ini, mengingat teknologi informasi dan komunikasi di satu sisi memiliki peran strategis dalam pengembangan Hak Cipta, tetapi di sisi lain juga menjadi alat untuk pelanggaran hukum di bidang ini. Pengaturan yang proporsional sangat diperlukan, agar fungsi

\footnotetext{
2 Undang-Undang RI, Nomor 28 Tahun 2014, L.N.RI Tahun 2014, Nomor 266, Bagian Menimbang huruf d.

3 Id, Alinea ke 4 Penjelasan Umum.
} 
positif dapat dioptimalkan dan dampak negatifnya dapat diminimalkan ${ }^{4}$. Perkembangan dan kemajuan Teknologi Informasi yang demikian pesat telah menyebabkan perubahan kegiatan kehidupan manusia dalam berbagai bidang yang secara langsung telah memengaruhi lahirnya bentuk-bentuk perbuatan hukum baru. ${ }^{5}$ Pemanfaatan Teknologi Informasi, media, dan komunikasi telah mengubah baik perilaku masyarakat maupun peradaban manusia secara global. Perkembangan teknologi informasi dan komunikasi telah pula menyebabkan hubungan dunia menjadi tanpa batas (borderless) dan menyebabkan perubahan sosial, ekonomi, dan budaya secara signifikan berlangsung demikian cepat. Teknologi Informasi saat ini menjadi pedang bermata dua karena selain memberikan kontribusi bagi peningkatan kesejahteraan, kemajuan, dan peradaban manusia, sekaligus menjadi sarana efektif perbuatan melawan hukum. ${ }^{6}$

Saat ini telah lahir suatu rezim hukum baru yang dikenal dengan hukum siber atau hukum telematika. Hukum siber atau Cyber Law, secara internasional digunakan untuk istilah hukum yang terkait dengan pemanfaatan teknologi informasi dan komunikasi. Demikian pula, hukum telematika yang merupakan perwujudan dari konvergensi hukum telekomunikasi, hukum media, dan hukum informatika. Istilah lain yang juga digunakan adalah hukum teknologi informasi (law of information technology), hukum dunia maya (virtual world law), dan hukum mayantara. Istilah-istilah tersebut lahir mengingat kegiatan yang dilakukan melalui jaringan sistem komputer dan sistem komunikasi baik dalam lingkup lokal maupun global (Internet) dengan memanfaatkan teknologi informasi berbasis sistem komputer yang merupakan sistem elektronik yang dapat dilihat secara virtual. Hal itu berakibat terhadap perlindungan karya cipta secara manual, sehingga dengan munculnya rezim hukum baru yang berkaitan dengan

\footnotetext{
4 Id, Alinea kedua Penjelasan Umum.

5 Undang-Undang Nomor 11 Tahun 2008, Lembaran Negara Republik Indonesia Tahun 2008 Nomor 5 Tentang Informasi dan Transaksi Elektronik, Bagian Menimbang huruf c.

6 Id, Penjelasan Umum UU ITE.
} 
perkembangan teknologi dan informasi melalui internet (Cyber Law), perlu dikaji lebih cermat substansi UU No 28 Tahun 2014 Tentang Hak Cipta.

\section{Kajian teori Kekayaan Intelektual}

Negara hukum mempunyai beberapa ciri, antara lain adanya perlindungan Hak Asasi manusia, yaitu:

"Setiap orang berhak mengembangkan diri melalui pemenuhan kebutuhan dasarnya, berhak mendapat pendidikan dan memperoleh manfaat dari ilmu pengetahuan dan teknologi, seni dan budaya, demi meningkatkan kualitas hidupnya dan demi kesejahteraan umat manusia". ${ }^{7}$

Kepemilikan KI pada hakekatnya merupakan hak asasi ekonomi (property right) yang diperoleh pencipta atas pemanfaatan ilmu pengetahuan, seni , dan sastra untuk meningkatkan kesejahteraan dalam perspektif negara hukum. Berdasarkan hal itu, Indonesia tidak hanya melindungi hak asasi warga negaranya, tetapi lebih jauh lagi untuk meningkatkan kualitas hidup demi kesejahteraannya, sehingga Indonesia menganut konsep sebagai negara kesejahteraan (negara hukum dalam arti materil). Teori Negara Kesejahteraan menjelaskan bahwa Negara berperan meningkatkan pemerataan pertumbuhan ekonomi menuju ke arah peningkatan kesejahteraan rakyat. Konsep ini merupakan landasan filosofis yuridis sebagaimana tercantum dalam Pembukaan UUD 1945 Alinea ke IV yang kemudian dijabarkan dalam Pasal 33 Undang-Undang Dasar $1945 .^{8}$

Perlindungan KI secara universal tercantum dalam Pasal 27 Declaration of Human Rights (10 Desember 1948) berbunyi: ${ }^{9}$

${ }^{7}$ Undang-Undang Dasar Republik Indonesia Amandemen ke 4, Pasal 28C.

${ }^{8}$ Id, Pasal 33.

${ }^{9}$ Pan Panhuys, International Organization and Integration: A Collection of the Text odf Document Relating to the United Nation, its Related Agencies and Regional International, Cornelis van Vollenhoven, Leyden and the Europe Institute, 1968, page 249. Lihat juga, Ranti Fauza Mayana, 
1. Everyone has the right freely to participate in the cultural life of community, to enjoy the arts and to share in scientific advancement and its benefits.

2. Everyone has the right to protection of moral and material interest resulting from any scientific, literary or artistic production of which he is the author.

$\mathrm{KI}^{10}$ adalah hak yang dimiliki di bidang ilmu pengetahuan, seni, sastra, teknologi, bisnis dan industri sebagai hasil kreasi atau inovasi dari intelektualnya. Eddy Damian berpendapat bahwa KI yang timbul dari kemampuan intelektual seseorang adalah bentuk perwujudan alter ego (refleksi kepribadiannya) atau kualitas rasa, karsa, dan cipta nalarnya. ${ }^{11}$ Pada umumnya, KI merupakan hasil pemecahan atas masalah yang dihadapi oleh seseorang, yang sesuai dengan kodratnya akan terdorong untuk berpikir secara kreatif guna memecahkan suatu masalah yang dialaminya. Kreativitas tersebut selanjutnya memicu daya cipta untuk menghasilkan karya intelektual. ${ }^{12}$ W.R Cornish mengatakan ${ }^{13}$ "KI melindungi pemakaian idea dan informasi yang mempunyai nilai komersil atau nilai ekonomi". Sedangkan David I Bainbridge mengatakan "Intellectual property" is the collective name given to legal rights which protect the produk of human intellect. ${ }^{14}$ The term intellectual property seem to be the best available to cover that body of legal rights which arise from mental and artistic endeavour. ${ }^{15}$

Perlindungan Desain Industri Di Indonesia dalam Era Perdagangan Bebas, Grasinso, Jakarta, 2004, hlm 16.

${ }^{10}$ Kekayaan Intelektual konvensional pada dasarnya dibagi ke dalam 2 bagian, yaitu Hak Cipta dan Turunannya, dan Hak Kekayaan Perindustrian yang mencakup: Paten, Merek, Rahasia Dagang, Desain Indutri, Perlindungan Varietas Tanaman, dan Desain Tata Letak Sirkuit Terpadu.

${ }^{11}$ Penjelasan lengkap lihat Eddy Damian, Hukum Hak Cipta Menurut Beberapa Konvensi Internasional, Undang-Undang Hak Cipta 1997 dan Perlindungan Terhadap Buku serta Perjanjian Penerbitnnya, Alumni, Bandung, 1999, hlm 41-44.

${ }^{12}$ Direktorat Jenderal Kekayaan Intelektual, 2004, hlm 5.

${ }^{13}$ W.R Cornish, Intelectual Property, second edition, Sweer \& Maxwell, London, 1989, hlm 5.

${ }^{14}$ David I Bainbridge, Computers and The Law, Pitman Publishing, first edition, London, 1990, hlm. 7.

15 John F William, A Manager's Guide to Patent, Trade Marks \& Copyright, Kogan Page, first edition, London, 1986, page 11. Sedangkan Robert M. Sherwood menjelaskan KI sebagai berikut: Intellectual Property is a compounding of things. First, it is ideas, inventions and creative 
Kepemilikan berkaitan erat dengan ajaran Hukum Alam yang dikemukakan oleh Hugo de Groot (Grotius, 1583-1645) karena Hukum Alam dipandang sebagai pencetusan rasio manusia yang berkaitan dengan apakah suatu tingkah laku manusia itu dianggap baik atau buruk, apakah tindakan manusia itu dapat diterima atau ditolak atas dasar kesusilaan alam. Empat Prinsip Dasar dalam Hukum Alam adalah (1) Prinsip kupunya dan kau punya, artinya Milik orang lain harus dijaga. (2) Prinsip kesetiaan pada janji, (3) Prinsip ganti rugi, dan (4) Prinsip perlunya hukuman. ${ }^{16}$ Sejalan dengan itu, konsep hak milik dipengaruhi oleh pemikiran John Locke, yang mengatakan bahwa hak milik dari seorang manusia terhadap benda yang dihasilkannya itu sudah ada sejak manusia lahir. Pengertian benda tidak hanya benda yang berwujud tetapi juga benda yang abstrak, yang disebut dengan hak milik atas benda yang tidak berwujud yang merupakan hasil dari intelektualitas manusia. ${ }^{17}$

Nico Kansil menjelaskan teori yang mendasari perlindungan hukum terhadap KI, yaitu: ${ }^{18}$

1. Teori Reward, bahwa pencipta di bidang ilmu pengetahuan, seni dan sastra, serta penemu di bidang teknologi baru yang mengandung langkah inovatif serta dapat diterapkan dalam industri, diberikan suatu penghargaan dan pengakuan serta

expression. They are essentially the result of private activity. Second, it is public willingness to bestow the status of property on those inventions ang expression. The most common technique for conferring a protected status are trade secret, the patent, copyright and the trademark with one new category for mask work (or chips). The term "intellectual property" contains both the concept of private creativity and the concept of public protection for the result of creativity. For analytical purposes. It is useful to apply the term "product of mind" or perharps "intellectual assets" to those ideas, inventions and creative expressions collectively. Lihat Robert M. Sherwood, Intellectual Property and Economic Development: Westview Special Studies in Science, Technology and Public Policy, Westview Press Inc, San Fransisco, 1990, hlm. 11-13.

16 Theo Huijbers OSC, Filsafat Hukum dalam Lintasan Sejarah, Kanisius, Jakarta, 1984, hlm 60 Lihat juga https://kuliahade.wordpress.com/2010/01/31/filsafat-hukum-hukum-alam/ (terakhir diakses 12 Agustus 2016).

17 Locke, Two Treatises of Government, edited and introduced by Peter Laslett, 1988, hlm. 285. Lihat juga Syafrinaldi, Hukum Tentang Perlindungan Hak Milik Intelektual Dalam Menghadapi Era Globalisasi, UIR Press, Jakarta, 2010, hlm. 7.

18 Nico Kansil, Perlindungan Hukum terhadap KI, Makalah pada Seminar Nasional KI, UNDIP Semarang, tanggal 27 April 1993. Lihat juga Ranti Fauza Mayana, supra, hlm. 44-46. 
perlindungan atas keberhasilan upayanya dalam melahirkan ciptaan baru itu;

2. Teori Recovery, bahwa atas usaha dari pencipta dan penemu yang telah mengeluarkan tenaga, pikiran, waktu dan biaya yang tidak sedikit jumlahnya, kepadanya diberikan hak eksklusif untuk mengeksploitasi KI guna meraih kembali yang telah dikeluarkannya;

3. Teori Incentif, bahwa insentif diberikan untuk merangsang kreativitas dan upaya menciptakan karya-karya baru di bidang teknologi;

4. Teori Public Benefit, bahwa KI merupakan suatu alat untuk meraih dan mengembangkan ekonomi.

Salah satu jenis KI adalah Hak Cipta yaitu hak eksklusif pencipta yang timbul secara otomatis berdasarkan prinsip deklaratif setelah suatu ciptaan diwujudkan dalam bentuk nyata tanpa mengurangi pembatasan sesuai dengan ketentuan peraturan perundang-undangan. ${ }^{19}$ Ciptaan adalah setiap hasil karya cipta di bidang ilmu pengetahuan, seni, dan sastra yang dihasilkan atas inspirasi, kemampuan, pikiran, imajinasi, kecekatan, keterampilan, atau keahlian yang diekspresikan dalam bentuk nyata. ${ }^{20}$

Sistem perlindungan dalam hukum KI, khususnya hak cipta meliputi: subyek perlindungan, obyek perlindungan dan yang pengecualian atau pembatasan, stelsel pendaftaran, jangka waktu perlindungan, dan perbuatan pihak lain serta tindakan oleh pencipta atau pemegang hak cipta apabila terjadi pelanggaran oleh pihak lain. Sistem perlindungan tersebut perlu diharmonisasikan dengan Cyber Law sebagai akibat perkembangan teknologi informasi melalui internet.

Cyber Law berasal dari cyberspace law yang ruang lingkupnya meliputi setiap aspek yang berhubungan dengan subyek hukum yang menggunakan dan memanfaatkan teknologi internet, dimulai pada saat online dan memasuki

\footnotetext{
19 Undang-Undang RI, Nomor 28 Tahun 2014, supra pada Pasal 1 Angka 1.

20 Id, Pasal 1 Angka 3.
} 
cyberspace atau dunia maya. Istilah ini sering digunakan untuk hukum yang terkait dengan pemanfaatan teknologi informasi. Dengan demikian, Cyber Law dapat diartikan pengertian umum yang mengacu kepada aspek regulasi atau perundangan-undangan dari teknologi informasi dalam cyber space. Sedangkan Teknologi Informasi adalah suatu teknik untuk mengumpulkan, menyiapkan, menyimpan, memproses, mengumumkan, menganalisis, dan/atau menyebarkan informasi. ${ }^{21}$ Dengan demikian, ada keterkaitan antara sistem perlindungan atas ciptaan berdasarkan UUHC dengan Cyber Law karena perkembangan teknologi informasi melalui internet akan berakibat pada ketentuan yang mengatur karya cipta.

\section{Hak Cipta dalam Perspektif Cyber Law}

Keterkaitan Hak Cipta dengan Cyber Law sebagaimana dikemukakan oleh Ahmad M Ramli mencakup: definisi, pengumuman dan penggandaan, program komputer, lembaga penyiaran, penggandaan rekaman suara, ciptaan yang dilindungi, pembatasan hak cipta dan cyber media, kepentingan ilmiah dan $e$ learning, informasi dan sarana teknologi, jangka waktu perlindungan, dan administrasi. 22

Berdasarkan sistem perlindungan atas ciptaan menurut pendapat Ahmad M Ramli, tersebut di atas terkait perspektif Cyber Law dapat diuraikan hal-hal sebagai berikut: ${ }^{23}$

\section{Subyek Perlindungan}

Pencipta adalah seorang atau beberapa orang yang secara sendiri-sendiri atau bersama-sama menghasilkan suatu ciptaan yang bersifat khas dan pribadi. ${ }^{24}$ Kecuali terbukti sebaliknya, yang dianggap sebagai Pencipta, yaitu Orang yang

21 Undang-Undang Nomor 11 Tahun 2008, supra, pada Pasal 1 Angka 2.

22 Ahmad M Ramli, Cyber Law dan HAKI Dalam Sistem Hukum Indonesia, Refika Aditama, Bandung, 2004, hlm 72 -81.

${ }^{23}$ Bandingkan dengan Ahmad M Ramli, Id.

24 Undang-Undang RI Nomor 28 Tahun 2014, supra, pada Pasal 1 Angka 2. 
namanya: a. disebut dalam Ciptaan; b. dinyatakan sebagai Pencipta pada suatu Ciptaan; c. disebutkan dalam surat pencatatan Ciptaan; dan/atau d. tercantum dalam daftar umum Ciptaan sebagai Pencipta. ${ }^{25}$ Pemegang Hak Cipta adalah Pencipta sebagai pemilik Hak Cipta, pihak yang menerima hak tersebut secara sah dari Pencipta, atau pihak lain yang menerima lebih lanjut hak dari pihak yang menerima hak tersebut secara sah. ${ }^{26}$

Dalam hal Ciptaan terdiri atas beberapa bagian tersendiri yang diciptakan oleh 2 (dua) Orang atau lebih, yang dianggap sebagai Pencipta yaitu Orang yang memimpin dan mengawasi penyelesaian seluruh Ciptaan. ${ }^{27}$ Dalam hal Orang yang memimpin dan mengawasi penyelesaian seluruh Ciptaan tidak ada, yang dianggap sebagai Pencipta yaitu Orang yang menghimpun Ciptaan dengan tidak mengurangi Hak Cipta masing-masing atas bagian Ciptaannya. ${ }^{28}$ Dalam hal Ciptaan dirancang oleh seseorang dan diwujudkan serta dikerjakan oleh Orang lain di bawah pimpinan dan pengawasan Orang yang merancang, yang dianggap Pencipta yaitu Orang yang merancang Ciptaan. ${ }^{29}$ Kecuali diperjanjikan lain Pemegang Hak Cipta atas Ciptaan yang dibuat oleh Pencipta dalam hubungan dinas, yang dianggap sebagai Pencipta yaitu instansi pemerintah. ${ }^{30}$ Dalam hal Ciptaan digunakan secara komersial, Pencipta dan/atau Pemegang Hak Terkait mendapatkan imbalan dalam bentuk Royalti. ${ }^{31}$ Kecuali diperjanjikan lain, Pencipta dan Pemegang Hak Cipta atas Ciptaan yang dibuat dalam hubungan kerja atau berdasarkan pesanan yaitu pihak yang membuat Ciptaan. ${ }^{32}$ Kecuali terbukti sebaliknya, dalam hal badan hukum melakukan Pengumuman, Pendistribusian, atau Komunikasi atas Ciptaan yang berasal dari badan hukum tersebut, dengan

\footnotetext{
25 Id, Pasal 31.

${ }^{26}$ Id, Pasal 1 Angka 4.

${ }^{27}$ Id, Pasal 33 Ayat (1).

${ }^{28}$ Id, Pasal 33 Ayat (2).

${ }^{29}$ Id, Pasal 34.

30 Id, Pasal 35 Ayat (1).

31 Id, Pasal 35 Ayat (2).

32 Id, Pasal 36.
} 
tanpa menyebut seseorang sebagai Pencipta, yang dianggap sebagai Pencipta yaitu badan hukum. ${ }^{33}$

Dalam perspektif Cyber Law, pencipta atau pemegang hak cipta yaitu pihak yang melakukan up load (unggah) dan atau namanya dicantumkan dalam ciptaan yang diunggah tersebut, kecuali dibuktikan lain.

Pencipta merupakan subyek hukum dari hak cipta, dalam arti pendukung hak dan kewajiban untuk menjalankan peranannya berkaitan dengan kepemilikannya. Oleh karena itu menurut Teori Reward, pencipta atau pemegang hak cipta diberikan suatu penghargaan dan pengakuan serta perlindungan atas keberhasilan upayanya dalam melahirkan ciptaan baru itu. Pencipta dalam melahirkan ciptaannya mengeluarkan banyak waktu, biaya dan pikiran sehingga diberikan hak untuk mengeksploitasi KI untuk meraih kembali yang telah dikeluarkannya sebagaimana Teori Recovery. Pemberian Insentif bagi pencipta untuk hak-hak yang diciptakan oleh pencipta diberikan berupa insentif untuk merangsang kreativitas dan upaya menciptakan karya-karya baru di bidang teknologi (Teori Incentif), sehingga KI merupakan suatu alat untuk meraih dan mengembangkan ekonomi (Teori Public Benefit).

Pencipta memiliki hak eksklusif yaitu menggunakan dan memanfaatkan dan menggunakan haknya dengan memperhatikan pembatasan menurut perundang-undangan dan melarang pihak lain untuk menggunakan atau memanfaatkan tanpa izinnya. Dalam kaitan dengan sifat eksklusif, Hilary Pearson dan Clifford Miller berpendapat : 34

"The term property refers to something capable of ownership. Ownership basically means right to posses, use anf dispose of property to the exclusion of others. If you own land you have the exclusive legal right to keep out everyone except those you choose to invite to visit. If you own a car you have the exclusive legal right to stop some one else

\footnotetext{
33 Id, Pasal 37.

${ }^{34}$ Hilary Pearson dan Clifford Miller, Commercial Exploitation of Intellectual Property, Blackstone Limited, London, 1990, hlm. 16. Lihat juga Ranti Fauza Mayana, supra, pada 41.
} 
driving it without your permission. If you own copyright in a copyright work you have several legal rights, including the exclusive right to prevent anyone copying the work."

Hak eksklusif terdiri atas hak moral (Pasal 5 sd 7 UUHC) dan hak ekonomi (Pasal 8 sd 19 UUHC). Hak moral ${ }^{35}$ tidak dapat dialihkan selama Pencipta masih hidup, tetapi pelaksanaan hak tersebut dapat dialihkan dengan wasiat atau sebab lain sesuai dengan ketentuan peraturan perundang-undangan setelah Pencipta meninggal dunia. Dalam hal terjadi pengalihan pelaksanaan hak moral penerima dapat melepaskan atau menolak pelaksanaan haknya dengan syarat pelepasan atau penolakan pelaksanaan hak tersebut dinyatakan secara tertulis. Untuk melindungi hak moral, Pencipta dapat memiliki: a. informasi manajemen Hak Cipta; dan/atau b. informasi elektronik Hak Cipta. Sedangkan hak ekonomi dapat beralih atau dialihkan, baik seluruh maupun sebagian karena: a. pewarisan; b. hibah; c. wakaf; d. wasiat; e. perjanjian tertulis; atau f. sebab lain yang dibenarkan sesuai dengan ketentuan peraturan perundang-undangan. Pencipta atau Pemegang Hak Cipta memiliki hak ekonomi untuk melakukan: a. penerbitan Ciptaan; b. Penggandaan Ciptaan dalam segala bentuknya; c. penerjemahan Ciptaan; d. pengadaptasian, pengaransemenan, atau pentransformasian Ciptaan; e. Pendistribusian Ciptaan atau salinannya; f. pertunjukan Ciptaan; g. Pengumuman Ciptaan; h. Komunikasi Ciptaan; dan i. penyewaan Ciptaan. ${ }^{36}$

\footnotetext{
35 Hak moral merupakan hak yang melekat secara abadi pada diri Pencipta untuk: a. tetap mencantumkan atau tidak mencantumkan namanya pada salinan sehubungan dengan pemakaian Ciptaannya untuk umum; b. menggunakan nama aliasnya atau samarannya; c. mengubah Ciptaannya sesuai dengan kepatutan dalam masyarakat; $d$. mengubah judul dan anak judul Ciptaan; dan e. mempertahankan haknya dalam hal terjadi distorsi Ciptaan, mutilasi Ciptaan, modifikasi Ciptaan, atau hal yang bersifat merugikan kehormatan diri atau reputasinya. Lihat Undang-Undang Nomor 28 Tahun 2014, supra, pada Pasal 5 Ayat (1).

${ }^{36}$ Id, Pasal 9 Ayat (1).
} 


\section{Obyek Perlindungan}

Ciptaan yang dilindungi meliputi Ciptaan dalam bidang ilmu pengetahuan, seni, dan sastra. Perincian secara lengkap tentang obyek hak cipta dapat dilihat dari ketentuan Pasal 40 Ayat (1) UUHC.37 Ciptaan berupa terjemahan, tafsir, saduran, bunga rampai, basis data, adaptasi, aransemen, modifikasi dan karya lain dari hasil transformasi dilindungi sebagai Ciptaan tersendiri dengan tidak mengurangi Hak Cipta atas Ciptaan asli. Pelindungan sebagaimana dimaksud, termasuk pelindungan terhadap Ciptaan yang tidak atau belum dilakukan Pengumuman $^{38}$ tetapi sudah diwujudkan dalam bentuk nyata yang memungkinkan Penggandaan ${ }^{39}$ Ciptaan tersebut. Dalam perspektif Cyber Law, maka ciptaan-ciptaan yang diunggah termasuk obyek yang dilindungi, misalnya on line book atau berkaitan dengan proses down load lagu-lagu MP3 melalui media internet. ${ }^{40}$

Program Komputer adalah seperangkat instruksi yang diekspresikan dalam bentuk bahasa, kode, skema, atau dalam bentuk apapun yang ditujukan agar komputer bekerja melakukan fungsi tertentu atau untuk mencapai hasil

\footnotetext{
${ }^{37}$ Id, Pasal 40 Ayat (1), Ciptaan yang dilindungi meliputi Ciptaan dalam bidang ilmu pengetahuan, seni, dan sastra, terdiri atas a. buku, pamflet, perwajahan karya tulis yang diterbitkan, dan semua hasil karya tulis lainnya;b. ceramah, kuliah, pidato, dan Ciptaan sejenis lainnya; c. alat peraga yang dibuat untuk kepentingan pendidikan dan ilmu pengetahuan; d. lagu dan/atau musik dengan atau tanpa teks; e. drama, drama musikal, tari, koreografi, pewayangan, dan pantomim; $\mathrm{f}$. karya seni rupa dalam segala bentuk seperti lukisan, gambar, ukiran, kaligrafi, seni pahat, patung, atau kolase; g. karya seni terapan; h. karya arsitektur; i. peta; j. karya seni batik atau seni motif lain; k. karya fotografi; l. Potret; m. karya sinematografi; n. terjemahan, tafsir, saduran, bunga rampai, basis data, adaptasi, aransemen, modifikasi dan karya lain dari hasil transformasi; o. terjemahan, adaptasi, aransemen, transformasi, atau modifikasi ekspresi budaya tradisional; $\mathrm{p}$. kompilasi Ciptaan atau data, baik dalam format yang dapat dibaca dengan Program Komputer maupun media lainnya; q. kompilasi ekspresi budaya tradisional selama kompilasi tersebut merupakan karya yang asli; r. permainan video; dan s. Program Komputer.

38 Pengumuman adalah pembacaan, penyiaran, pameran, suatu ciptaan dengan menggunakan alat apapun baik elektronik atau non elektronik atau melakukan dengan cara apapun sehingga suatu ciptaan dapat dibaca, didengar, atau dilihat orang lain. Id, Pasal 1 Angka 11.

39 Penggandaan adalah proses, perbuatan, atau cara menggandakan satu salinan Ciptaan dan/atau fonogram atau lebih dengan cara dan dalam bentuk apapun, secara permanen atau sementara. Id, Pasal 1 Angka 12.

${ }^{40}$ Bandingkan dengan Ahmad M Ramli, supra, hlm. 74.
} 
tertentu. ${ }^{41}$ Obyek perlindungan Hak Cipta seperti program komputer dan karyakarya lainnya di media internet perlu mendapat perlindungan UUHC. Dalam hal Undang-Undang tersebut belum memberikan perlindungan secara tegas, maka dapat dilakukan melalui penafsiran ekstentif (penafsiran diperluas), yaitu dengan cara memperluas makna obyek perlindungan tidak hanya yang bersifat manual tetapi meliputi virtual.

Setiap Orang dilarang merusak, memusnahkan, menghilangkan, atau membuat tidak berfungsi sarana kontrol teknologi yang digunakan sebagai pelindung Ciptaan atau produk Hak Terkait serta pengaman Hak Cipta atau Hak Terkait, kecuali untuk kepentingan pertahanan dan keamanan negara, serta sebab lain sesuai dengan ketentuan peraturan perundang-undangan, atau diperjanjikan lain. ${ }^{42}$ Apabila dikaitkan dengan Cyber Law, maka hal ini berkaitan dengan kewajiban menyimpan dokumen elektronik yang dapat diakses oleh pihak-pihak yang berkepentingan. ${ }^{43}$

Ciptaan atau produk Hak Terkait yang menggunakan sarana produksi dan/atau penyimpanan data berbasis teknologi informasi dan/atau teknologi tinggi, wajib memenuhi aturan perizinan dan persyaratan produksi yang ditetapkan oleh instansi yang berwenang. ${ }^{44}$ Dalam kaitan dengan perspektif $c y b e r$ law, teknologi informasi/sistem informasi yang digunakan untuk melindungi hak cipta juga dilindungi dari upaya destruktif yang juga dilakukan dengan teknologi maju. ${ }^{45}$

Kewenangan Pemerintah untuk melakukan pengawasan berkaitan dengan pelanggaran Hak Cipta dalam perspektif Cyber Law diatur dalam Pasal 54 UUHC. 46

\footnotetext{
41 Undang-Undang RI, Nomor 28 Tahun 2014, supra, pada Pasal 1 Angka 9.

42 Id, Pasal 51.

${ }^{43}$ Ahmad M Ramli, Supra, pada 78.

${ }^{44}$ Undang-Undang RI, Nomor 28 Tahun 2014, Id Pasal 53 Ayat (1).

${ }^{45}$ Ahmad M Ramli, supra, hlm. 79.

46 Undang-Undang RI, Nomor 28 Tahun 2014, supra, pada Pasal 54 "Untuk mencegah pelanggaran Hak Cipta dan Hak Terkait melalui sarana berbasis teknologi informasi, Pemerintah berwenang
} 
Sedangkan peran masyarakat untuk melaporkan setiap mengetahui pelanggaran Hak Cipta dan/atau Hak Terkait melalui sistem elektronik untuk Penggunaan Secara Komersial. ${ }^{47}$ Pelaporan dilakukan terhadap Menteri yang selanjutnya diverifikasi, dalam hal ditemukan bukti yang cukup berdasarkan hasil verifikasi laporan, atas permintaan pelapor Menteri merekomendasikan kepada menteri yang menyelenggarakan urusan pemerintahan di bidang telekomunikasi dan informatika untuk menutup sebagian atau seluruh konten yang melanggar Hak Cipta dalam sistem elektronik atau menjadikan layanan sistem elektronik tidak dapat diakses. Dalam hal penutupan situs Internet dilakukan secara keseluruhan, dalam waktu paling lama 14 (empat belas) hari wajib diminta penetapan pengadilan.

\section{Stelsel Pendaftaran}

Pendaftaran Ciptaan dan produk Hak Terkait bukan merupakan syarat untuk mendapatkan Hak Cipta dan Hak Terkait. ${ }^{48}$ Ketentuan ini menjelaskan bahwa Hak Cipta menganut stelsel deklaratif, artinya pendaftaran tidak merupakan kewajiban, pemegang hak adalah yang menggunakan terlebih dahulu (first to use). Namun pendaftaran ${ }^{49}$ dapat dilakukan untuk kepentingan pembuktian apabila muncul permasalahan dikemudian hari. Pihak penggugat (dalam hal ini pencipta atau pemegang Hak Cipta) harus membuktikan bahwa ia

melakukan: a. pengawasan terhadap pembuatan dan penyebarluasan konten pelanggaran Hak Cipta dan Hak Terkait; b. kerja sama dan koordinasi dengan berbagai pihak, baik dalam maupun luar negeri dalam pencegahan pembuatan dan penyebarluasan konten pelanggaran Hak Cipta dan Hak Terkait; dan c. pengawasan terhadap tindakan perekaman dengan menggunakan media apapun terhadap Ciptaan dan produk Hak Terkait di tempat pertunjukan.

47 Id, Pasal 55 dan 56.

48 Id, Pasal 64 Ayat (2).

49 Id, Pasal 66 Ayat (1) : Pencatatan Ciptaan dan produk Hak Terkait diajukan dengan Permohonan secara tertulis dalam bahasa Indonesia oleh Pencipta, Pemegang Hak Cipta, pemilik Hak Terkait, atau Kuasanya kepada Menteri. Pasal 66 Ayat (2): Permohonan dilakukan secara elektronik dan/atau non elektronik dengan: a. menyertakan contoh Ciptaan, produk Hak Terkait, atau penggantinya; b. melampirkan surat pernyataan kepemilikan Ciptaan dan Hak Terkait; dan c. membayar biaya. 
pemilik atau pemegang yang sah. ${ }^{50}$ Penerapan stelsel deklaratif dalam perspektif Cyber Law sangat bermanfaat untuk internet yang perlu serba praktis dan tanpa birokrasi yang berbelit. 51

Ketentuan UUHC tidak mencantumkan secara tegas adanya Sistem jaringan Dokumentasi dan Informasi Hak Cipta secara Nasional. Hal ini berbeda dengan UUHC 2002 yang mengatur melalui Pasal 53 UUHC 2002. Padahal keberadaan sistem jaringan tersebut yang didukung internet dan teknologi informasi merupakan hal yang vital dalam era digital, sehingga harus dipertahankan dan dikembangkan sebagai sarana informasi kepada pihak-pihak yang berkepentingan terhadap pencatatan Hak Cipta.

\section{Jangka Waktu}

Jangka waktu perlindungan menurut UU No. 28 Tahun 2014 agak berbeda dengan UU Hak Cipta sebelumnya (UU No. 19 Tahun 2002). UU Hak Cipta Tahun 2014 mengatur secara tegas masa berlakunya hak moral dan hak ekonomi. Masa berlakunya hak moral tercantum dalam Pasal 57 yang berbunyi:

(1) Hak moral Pencipta sebagaimana dimaksud dalam Pasal 5 Ayat (1) huruf a, huruf b, dan huruf e berlaku tanpa batas waktu.

(2) Hak moral Pencipta sebagaimana dimaksud dalam Pasal 5 Ayat (1) huruf $\mathrm{c}$ dan huruf d berlaku selama berlangsungnya jangka waktu Hak Cipta atas Ciptaan yang bersangkutan.

Selanjutnya, ketentuan Pasal 58 mengatur tentang Masa Berlaku Hak Ekonomi, yaitu:

(1) Pelindungan Hak Cipta atas Ciptaan:

a. buku, pamflet, dan semua hasil karya tulis lainnya;

b. ceramah, kuliah, pidato, dan Ciptaan sejenis lainnya;

c. alat peraga yang dibuat untuk kepentingan pendidikan dan ilmu pengetahuan;

d. lagu atau musik dengan atau tanpa teks;

\footnotetext{
${ }^{50}$ Kitab Undang-Undang Hukum Perdata, Pasal 1865.

${ }^{51}$ Ahmad M Ramli, supra hlm. 81.
} 
e. drama, drama musikal, tari, koreografi, pewayangan, dan pantomim;

f. karya seni rupa dalam segala bentuk seperti lukisan, gambar, ukiran, kaligrafi, seni pahat, patung, atau kolase;

g. karya arsitektur;

h. peta; dan

i. karya seni batik atau seni motif lain, berlaku selama hidup Pencipta dan terus berlangsung selama 70 (tujuh puluh) tahun setelah Pencipta meninggal dunia, terhitung mulai tanggal 1 Januari tahun berikutnya.

(2) Dalam hal Ciptaan sebagaimana dimaksud pada Ayat (1) dimiliki oleh 2 (dua) orang atau lebih, pelindungan Hak Cipta berlaku selama hidup Pencipta yang meninggal dunia paling akhir dan berlangsung selama 70 (tujuh puluh) tahun sesudahnya, terhitung mulai tanggal 1 Januari tahun berikutnya.

(3) Pelindungan Hak Cipta atas Ciptaan sebagaimana dimaksud pada Ayat (1) dan Ayat (2) yang dimiliki atau dipegang oleh badan hukum berlaku selama 50 (lima puluh) tahun sejak pertama kali dilakukan Pengumuman.

Pasal 59 UUHC

(1) Pelindungan Hak Cipta atas Ciptaan:

a. karya fotografi;

b. Potret;

c. karya sinematografi;

d. permainan video;

e. Program Komputer;

f. perwajahan karya tulis;

g. terjemahan, tafsir, saduran, bunga rampai, basis data, adaptasi, aransemen, modifikasi dan karya lain dari hasil transformasi;

h. terjemahan, adaptasi, aransemen, transformasi atau modifikasi ekspresi budaya tradisional;

i. kompilasi Ciptaan atau data, baik dalam format yang dapat dibaca dengan Program Komputer atau media lainnya; dan

j. kompilasi ekspresi budaya tradisional selama kompilasi tersebut merupakan karya yang asli, berlaku selama 50 (lima puluh) tahun sejak pertama kali dilakukan Pengumuman.

(2) Pelindungan Hak Cipta atas Ciptaan berupa karya seni terapan berlaku selama 25 (dua puluh lima) tahun sejak pertama kali dilakukan Pengumuman. 
Masa berlaku pelindungan Hak Cipta atas Ciptaan yang dilakukan Pengumuman bagian per bagian dihitung sejak tanggal Pengumuman bagian yang terakhir. ${ }^{52}$ Dalam menentukan masa berlaku pelindungan Hak Cipta atas Ciptaan yang terdiri atas 2 (dua) jilid atau lebih yang dilakukan Pengumuman secara berkala dan tidak bersamaan waktunya, setiap jilid Ciptaan dianggap sebagai Ciptaan tersendiri. ${ }^{53}$

Dalam perspektif Cyber Law seharusnya mendapat pelindungan yang sama dalam media internet tetapi jangka waktu lima puluh tahun untuk pelindungan komputer agak berlebihan mengingat program komputer sangat cepat berubah, 54 penulis berpendapat paling lama 5 tahun. Hal ini akan menjadi tidak rasional karena program komputer tersebut sudah tidak digunakan lagi (out of date), karena muncul program yang baru tetapi menurut hukum hak cipta, program komputer yang lama masih tetap mendapat pelindungan karena jangka waktunya belum 50 tahun.

\section{Pembatasan Hak Cipta}

Pembatasan Hak Cipta sebagaimana diatur dalam Pasal 43 dimaksudkan sebagai Perbuatan yang tidak dianggap sebagai pelanggaran Hak Cipta meliputi:

a. Pengumuman, Pendistribusian, Komunikasi, dan/atau Penggandaan lambang negara dan lagu kebangsaan menurut sifatnya yang asli;

b. Pengumuman, Pendistribusian, Komunikasi, dan/atau Penggandaan segala sesuatu yang dilaksanakan oleh atau atas nama pemerintah, kecuali dinyatakan dilindungi oleh peraturan perundang-undangan, pernyataan pada Ciptaan tersebut, atau ketika terhadap Ciptaan tersebut dilakukan Pengumuman, Pendistribusian, Komunikasi, dan/atau Penggandaan;

c. pengambilan berita aktual, baik seluruhnya maupun sebagian dari kantor berita, Lembaga Penyiaran, dan surat kabar atau sumber

52 Id, Pasal 61 Ayat (1).

53 Id, Pasal 61 Ayat (2).

${ }^{54}$ Ahmad M Ramli, supra, hlm. 79. 
sejenis lainnya dengan ketentuan sumbernya harus disebutkan secara lengkap; atau

d. pembuatan dan penyebarluasan konten Hak Cipta melalui media teknologi informasi dan komunikasi yang bersifat tidak komersial dan/atau menguntungkan Pencipta atau pihak terkait, atau Pencipta tersebut menyatakan tidak keberatan atas pembuatan dan penyebarluasan tersebut.

e. Penggandaan, Pengumuman, dan/atau Pendistribusian Potret Presiden, Wakil Presiden, mantan Presiden, mantan Wakil Presiden, Pahlawan Nasional, pimpinan lembaga negara, pimpinan kementerian/lembaga pemerintah non kementerian, dan/atau kepala daerah dengan memperhatikan martabat dan kewajaran sesuai dengan ketentuan peraturan perundang-undangan.

Penggandaan sementara atas Ciptaan tidak dianggap pelanggaran Hak Cipta jika Penggandaan tersebut memenuhi ketentuan: ${ }^{55}$ a. pada saat dilaksanakan transmisi digital atau pembuatan Ciptaan secara digital dalam media penyimpanan; b. dilaksanakan oleh setiap Orang atas izin Pencipta untuk mentransmisi Ciptaan; dan c. menggunakan alat yang dilengkapi mekanisme penghapusan salinan secara otomatis yang tidak memungkinkan Ciptaan tersebut ditampilkan kembali. Setiap Lembaga Penyiaran dapat membuat rekaman sementara tanpa izin Pencipta atau Pemegang Hak Cipta untuk tujuan aktivitasnya dengan alat dan fasilitasnya sendiri. ${ }^{56}$ Lembaga Penyiaran wajib memusnahkan rekaman sementara dalam waktu paling lama 6 (enam) bulan sejak pembuatan atau dalam waktu yang lebih lama dengan persetujuan Pencipta. ${ }^{57}$ Lembaga Penyiaran dapat membuat 1 (satu) salinan rekaman sementara yang mempunyai karakteristik tertentu untuk kepentingan arsip resmi. ${ }^{58}$

Pembatasan Hak Cipta bermakna bahwa Hak Cipta tidak absolut, karena hukum yang memberikan hak kepada seseorang perlu juga memperhatikan halhal lain dengan membatasi hak yang telah dimiliki tersebut agar dapat tercipta

\footnotetext{
55 Undang-Undang RI, Nomor 28 Tahun 2014, supra, pada Pasal 49 Ayat (1).

56 Id, Pasal 49 Ayat (2).

57 Id, Pasal 49 Ayat (3).

58 Id, Pasal 49 Ayat (4).
} 
tata kehidupan yang serasi dan seimbang. Namun demikian, pembatasan hak tersebut harus dicantumkan secara tegas dalam perundang-undangan, sehingga pihak yang haknya dibatasi tidak merasa diperlakukan sewenang-wenang karena memang sudah ada norma pengaturannya, di sisi lain pihak yang berwenang membatasi hak seseorang mempunyai dasar pembenaran untuk melakukan pembatasan tersebut. Hal ini sesuai dengan tujuan hukum yaitu mewujudkan keadilan sebagaimana dikemukakan oleh Aristoteles dan kemanfaatan berdasarkan teori kegunaan (utility theory) dari Jeremy Bentham serta menjamin kepastian hukum sesuai dengan pendapat John Austin.

Setiap Orang dilarang melakukan Pengumuman, Pendistribusian, atau Komunikasi Ciptaan yang bertentangan dengan moral, agama, kesusilaan, ketertiban umum, atau pertahanan dan keamanan negara. ${ }^{59}$ Dalam perspektif Cyber Law, terdapat undang-undang yang terkait dengan ketentuan ini yaitu Pasal 27 UU ITE , yang berbunyi:

(1) Setiap Orang dengan sengaja dan tanpa hak mendistribusikan dan/atau mentransmisikan dan/atau membuat dapat diaksesnya Informasi Elektronik dan/atau Dokumen Elektronik yang memiliki muatan yang melanggar kesusilaan.

(2) Setiap Orang dengan sengaja dan tanpa hak mendistribusikan dan/atau mentransmisikan dan/atau membuat dapat diaksesnya Informasi Elektronik dan/atau Dokumen Elektronik yang memiliki muatan perjudian.

(3) Setiap Orang dengan sengaja dan tanpa hak mendistribusikan dan/atau mentransmisikan dan/atau membuat dapat diaksesnya Informasi Elektronik dan/atau Dokumen Elektronik yang memiliki muatan penghinaan dan/atau pencemaran nama baik.

(4) Setiap Orang dengan sengaja dan tanpa hak mendistribusikan dan/atau mentransmisikan dan/atau membuat dapat diaksesnya Informasi Elektronik dan/atau Dokumen Elektronik yang memiliki muatan pemerasan dan/atau pengancaman.

59 Undang-Undang Nomor 11 Tahun 2008, supara, pada Pasal 50. 
Pemerintah dapat menyelenggarakan Pengumuman, Pendistribusian, atau Komunikasi atas suatu Ciptaan melalui radio, televisi dan/atau sarana lain untuk kepentingan nasional tanpa izin dari Pemegang Hak Cipta, dengan ketentuan wajib memberikan imbalan kepada Pemegang Hak Cipta. ${ }^{60}$ Lembaga Penyiaran yang melakukan Pengumuman, Pendistribusian, atau Komunikasi atas Ciptaan berhak mendokumentasikan Ciptaan hanya untuk Lembaga Penyiaran tersebut dengan ketentuan untuk Penyiaran selanjutnya, Lembaga Penyiaran tersebut harus mendapatkan izin Pemegang Hak Cipta. ${ }^{61}$ Berkaitan dengan perbuatanperbuatan tersebut melalui internet, perlu dikaji lebih lanjut pengambilan berita dari cyber media yang dijadikan sumber berita oleh media massa lainnya. ${ }^{62}$

\section{Kepentingan pendidikan \& penelitian, keamanan, hiburan.}

Penggunaan, pengambilan, Penggandaan, dan/atau pengubahan suatu Ciptaan dan/atau produk Hak Terkait secara seluruh atau sebagian yang substansial tidak dianggap sebagai pelanggaran Hak Cipta jika sumbernya disebutkan atau dicantumkan secara lengkap untuk keperluan:63

a. pendidikan, penelitian, penulisan karya ilmiah, penyusunan laporan, penulisan kritik atau tinjauan suatu masalah dengan tidak merugikan kepentingan yang wajar dari Pencipta atau Pemegang Hak Cipta;

b. keamanan serta penyelenggaraan pemerintahan, legislatif, dan peradilan;

c. ceramah yang hanya untuk tujuan pendidikan dan ilmu pengetahuan; atau

d. pertunjukan atau pementasan yang tidak dipungut bayaran dengan ketentuan tidak merugikan kepentingan yang wajar dari Pencipta.

\footnotetext{
60 Undang-Undang RI, Nomor 28 Tahun 2014, supra, pada Pasal 51 Ayat (1) .

61 Id, Pasal 51 Ayat (2).

62 Ahmad M Ramli, supra, hlm., 76.

63 Undang-Undang RI, Nomor 28 Tahun 2014, supra, pada Pasal 44 Ayat (1).
} 
Penggandaan sebanyak 1 (satu) salinan atau adaptasi Program Komputer yang dilakukan oleh pengguna yang sah dapat dilakukan tanpa izin Pencipta atau Pemegang Hak Cipta jika salinan tersebut digunakan untuk: ${ }^{64}$ a. penelitian dan pengembangan Program Komputer tersebut; dan b. arsip atau cadangan atas Program Komputer yang diperoleh secara sah untuk mencegah kehilangan, kerusakan, atau tidak dapat dioperasikan. Apabila penggunaan Program Komputer telah berakhir, salinan atau adaptasi Program Komputer tersebut harus dimusnahkan. 65

Penggandaan untuk kepentingan pribadi atas Ciptaan yang telah dilakukan Pengumuman hanya dapat dibuat sebanyak 1 (satu) salinan dan dapat dilakukan tanpa izin Pencipta atau Pemegang Hak Cipta. ${ }^{66}$ Penggandaan untuk kepentingan pribadi tidak mencakup: 67 a. karya arsitektur dalam bentuk bangunan atau konstruksi lain; b. seluruh atau bagian yang substansial dari suatu buku atau notasi musik; c. seluruh atau bagian substansial dari database dalam bentuk digital; d. Program Komputer, kecuali Penggandaan sebanyak 1 (satu) salinan atau adaptasi Program Komputer yang dilakukan oleh pengguna yang sah dapat dilakukan tanpa izin Pencipta atau Pemegang Hak Cipta jika salinan tersebut digunakan untuk: a. penelitian dan pengembangan Program Komputer tersebut; dan b. arsip atau cadangan atas Program Komputer yang diperoleh secara sah untuk mencegah kehilangan, kerusakan, atau tidak dapat dioperasikan. dan e. Penggandaan untuk kepentingan pribadi yang pelaksanaannya bertentangan dengan kepentingan yang wajar dari Pencipta atau Pemegang Hak Cipta.

Setiap perpustakaan atau lembaga arsip yang tidak bertujuan komersial dapat membuat 1 (satu) salinan Ciptaan atau bagian Ciptaan tanpa izin Pencipta

\footnotetext{
${ }^{64}$ Id, Pasal 45 Ayat (1).

65 Id, Pasal 45 Ayat (2).

66 Id, Pasal 46 Ayat (1).

67 Id, Pasal 46 Ayat (2).
} 
atau Pemegang Hak Cipta dengan cara: ${ }^{68}$ a. Penggandaan tulisan secara reprografi yang telah dilakukan Pengumuman, diringkas, atau dirangkum untuk memenuhi permintaan seseorang dengan syarat: 1. perpustakaan atau lembaga arsip menjamin bahwa salinan tersebut hanya akan digunakan untuk tujuan pendidikan atau penelitian; 2. Penggandaan tersebut dilakukan secara terpisah dan jika dilakukan secara berulang, Penggandaan tersebut harus merupakan kejadian yang tidak saling berhubungan; dan 3. tidak ada Lisensi yang ditawarkan oleh Lembaga Manajemen Kolektif kepada perpustakaan atau lembaga arsip sehubungan dengan bagian yang digandakan. b. pembuatan salinan dilakukan untuk pemeliharaan, penggantian salinan yang diperlukan, atau penggantian salinan dalam hal salinan hilang, rusak, atau musnah dari koleksi permanen di perpustakaan atau lembaga arsip lain dengan syarat: 1. perpustakan atau lembaga arsip tidak mungkin memperoleh salinan dalam kondisi wajar; atau 2. pembuatan salinan tersebut dilakukan secara terpisah atau jika dilakukan secara berulang, pembuatan salinan tersebut harus merupakan kejadian yang tidak saling berhubungan. c. pembuatan salinan dimaksudkan untuk Komunikasi atau pertukaran informasi antarperpustakaan, antarlembaga arsip, serta antara perpustakaan dan lembaga arsip.

Penggandaan, Penyiaran, atau Komunikasi atas Ciptaan untuk tujuan informasi yang menyebutkan sumber dan nama Pencipta secara lengkap tidak dianggap pelanggaran Hak Cipta dengan ketentuan Ciptaan berupa: ${ }^{69}$ a. artikel dalam berbagai bidang yang sudah dilakukan Pengumuman baik dalam media cetak maupun media elektronik kecuali yang salinannya disediakan oleh Pencipta, atau berhubungan dengan Penyiaran atau Komunikasi atas suatu Ciptaan; b. laporan peristiwa aktual atau kutipan singkat dari Ciptaan yang dilihat atau

\footnotetext{
68 Id, Pasal 47.

${ }^{69}$ Id, Pasal 48.
} 
didengar dalam situasi tertentu; dan c. karya ilmiah, pidato, ceramah, atau Ciptaan sejenis yang disampaikan kepada publik.

Berkaitan dengan teknologi dan informasi melalui internet, pengecualian terhadap penggunaan, pengambilan, Penggandaan, dan/atau pengubahan suatu Ciptaan harus juga diberlakukan, misalnya untuk e-learning. ${ }^{70}$

Hukum adalah kaidah heteronom, artinya kaidah yang tidak dapat berdiri sendiri karena mengatur pergaulan dalam masyarakat, sehingga kaidah hukum harus memberikan keseimbangan antara kepentingan individu dengan kepentingan masyarakat. Oleh karena itu penggunaan Hak Cipta tidak sematamata untuk menjamin kepentingan pribadi pencipta, tetapi juga memiliki fungsi sosial untuk kepentingan masyarakat luas.

Dalam konteks bangsa Indonesia yang berfalsafah Pancasila, kepentingan individu harus diposisikan dengan kepentingan umum, sehingga kedua kepentingan tersebut dapat berjalan sinergi. Cara berpikir masyarakat (adat) antara lain bersifat komunal sebagaimana pendapat Holleman harus diartikan bukan mementingkan kepentingan umum di atas kepentingan pribadi, tetapi menempatkan kepentingan pribadi selaras dengan kepentingan umum. Namun, dalam hal-hal tertentu perlu diakui bahwa kepentingan umum harus lebih diutamakan dari kepentingan pribadi. ${ }^{71}$

Berdasarkan uraian di atas, perlindungan hukum terhadap kreasi dan inovasi yang menimbulkan hak eksklusif (dengan berbagai pembatasannya) berupa hak ekonomi dan hak moral serta tindakan hukum yang dapat dilakukan oleh pencipta berdasarkan UUHC dikaitkan dengan cyber law merupakan kebijakan negara untuk menjamin kepastian hukum, keadilan dan kemanfaatan demi meningkatkan taraf hidup rakyatnya sesuai dengan "Negara Kesejahteraan".

\footnotetext{
${ }^{70}$ Ahmad M Ramli, supra, hlm. 77.

71 Bandingkan dengan Samidjo, Pengantar Hukum Indonesia, Armico, Bandung, 1985, hlm. 56.
} 


\section{Penutup}

Hasil kajian menunjukkan bahwa dalam perspektif Cyber law, beberapa ketentuan yang mengatur sistem perlindungan atas ciptaan berdasarkan UndangUndang Nomor 28 tahun 2014 belum sepenuhnya mengakomodasi perkembangan teknologi informasi secara virtual, yakni mengenai subyek perlindungan, obyek perlindungan, stelsel pendaftaran, jangka waktu, pembatasan hak cipta dan kepentingan pendidikan dan penelitian.

Beberapa ketentuan dalam UU No. 28 Tahun 2014 yakni subyek perlindungan, obyek perlindungan, stelsel pendaftaran, jangka waktu, pembatasan hak cipta dan kepentingan pendidikan dan penelitian perlu disesuaikan (harmonisasi) dengan perkembangan teknologi secara virtual sehingga dapat menjamin kepastian hukum, keadilan dan kemanfaatan.

\section{Daftar Pustaka}

\section{Buku:}

Ahmad M Ramli, Cyber Law dan HAKI Dalam Sistem Hukum Indonesia, Refika Aditama, Bandung, 2004.

David I Bainbridge, Computers and The Law, Pitman Publishing, first edition, London, 1990.

Eddy Damian, Hukum Hak Cipta Menurut Beberapa Konvensi Internasional, Undang-Undang Hak Cipta 1997 dan Perlindungan Terhadap Buku serta Perjanjian Penerbitnnya, Alumni, Bandung, 1999.

Hilary Pearson dan Clifford Miller, Commercial Exploitation of Intellectual Property, Blackstone Limited, London, 1990,

John F William, A Manager's Guide to Patent, Trade Marks \& Copyright, Kogan Page, first edition, London, 1986.

Locke, Two Treatises of Government, edited and introduced by Peter Laslett, 1988

Pan Panhuys, International Organization and Integration: A Collection of the Text of Document Relating to the United Nation, its Related Agencies and Regional International, Cornelis van Vollenhoven, Leyden and the Europe Institute, 1968.

Ranti Fauza Mayana, Perlindungan Desain Industri Di Indonesia dalam Era Perdagangan Bebas, Grasinsdo, Jakarta, 2004. 
Robert M. Sherwood, Intellectual Property and Economic Development : Westview Special Studies in Science, Technology and Public Policy, Westview Press Inc, San Fransisco, 1990.

Samidjo, Pengantar Hukum Indonesia, Armico, Bandung, 1985.

Syafrinaldi, Hukum Tentang Perlindungan Hak Milik Intelektual Dalam Menghadapi Era Globalisasi, UIR Press, Jakarta, 2010.

Theo Huijbers OSC, Filsafat Hukum dalam Lintasan Sejarah, Kanisius, Jakarta, 1984.

W.R Cornish, Intelectual Property, second edition, Sweer \& Maxwell, London, 1989.

\section{Pustaka tidak dipublikasi:}

Direktorat Jenderal Hak Kekayaan Intelektual, 2004.

Nico Kansil, Perlindungan Hukum terhadap KI, Makalah pada Seminar Nasional KI, UNDIP Semarang, tanggal 27 April 1993.

\section{Web Dokumen:}

http://id.wikipedia.org/wiki/Kekayaan_intelektual. (terakhir diakses 10 Agustus 2015).

https://kuliahade.wordpress.com/2010/01/31/filsafat-hukum-hukum-alam/

(terakhir diakses 12 Agustus 2016).

\section{Undang-Undang:}

Undang-Undang Dasar 1945 Amandemen ke 4.

Kitab Undang-Undang Hukum Perdata.

Undang-Undang Nomor 28 tahun 2014, L.N.RI Tahun 2014, Nomor 266 Tentang Hak Cipta.

Undang-Undang Nomor 11 Tahun 2008, Lembaran Negara Republik Indonesia Tahun 2008 Nomor 5 Tentang Informasi dan Transaksi Elektronik. 